\title{
Faktor Pemanfaatan Imunisasi Inactivated Polio Vaccine (IPV)
}

\section{Utilization Factors of Inactivated Polio Vaccine (IPV) Immunization}

\author{
Icon Harizon ${ }^{1}$, Misnaniarti ${ }^{2}$, Haerawati Idris ${ }^{3}$ \\ ${ }^{1}$ Dinas Kesehatan Provinsi Sumatera Selatan, Palembang, Indonesia \\ ${ }^{2,3}$ Fakultas Kesehatan Masyarakat, Universitas Sriwijaya, Indonesia
}

\section{ARTICLE INFO}

\section{Article history:}

Received date

13 Feb 2019

Revised date

01 Mar 2020

11 Mar 2020

Accepted date

23 April 2020

\section{Keywords:}

Immunization;

IPV Immunization;

Utilization;

Utilization services.

Kata kunci:

Imunisasi;

Imunisasi IPV;

Pemanfaatan;

Pemanfaatan layanan.

\author{
ABSTRACT/ ABSTRAK
}

The low utilization of IPV immunization services in Palembang in 2017 was 66,7\% while the national target was $95 \%$. The purpose of this study was to determine the factors associated with the utilization of IPV immunization services in Palembang. The study was conducted in September-October 2018, the population was 3570 mothers who had babies who were targeted by IPV immunization, 400 samples of mothers who have babies are targeted by IPV immunization in 5 health centers in Palembang by random sampling. Research using quantitative methods with crosssectional design. Data collection instruments were questionnaires based on the concept of health trust models, interviews, and observations, the data were analyzed using multiple logistic regression. The results showed that $84.5 \%$ of mothers used IPV immunization services in Palembang. The results of multiple logistic regression showed that the family support variable $(P R=2,015)$, knowledge of the mother variable $(\mathrm{PR}=2,164)$, the availability of health care facility variables $(\mathrm{PR}=2,376)$, and variable support for health workers $(P R=3,601)$ affect the utilization of IPV immunization services in Palembang City. Conclusion: variable support for health workers is the variable that has the greatest influence on the utilization of IPV immunization services in Palembang.

Rendahnya pemanfaatan layanan imunisasi IPV di kota Palembang pada tahun 2017 sebesar $66,7 \%$ sedangkan target nasional adalah 95\%. Tujuan penelitian untuk mengetahui faktor-faktor yang berhubungan dengan pemanfaatan layanan imunisasi IPV di Kota Palembang. Penelitian dilakukan pada bulan September-Oktober 2018, populasi penelitian seluruh ibu yang memiliki bayi yang ditargetkan dengan imunisasi IPV, 400 sampel ibu yang memiliki bayi ditargetkan dengan imunisasi IPV di 5 puskesmas di palembang dengan cara random sampling. Penelitian menggunakan metode kuantitatif dengan desain cross sectional. Instrumen pengumpulan data adalah kuesioner berdasarkan konsep model kepercayaan kesehatan, wawancara dan observasi, data dianalisis menggunakan regresi logistik ganda. Hasil penelitian menunjukkan bahwa $84,5 \%$ ibu menggunakan layanan imunisasi IPV di kota Palembang. Hasil regresi logistik ganda menunjukkan bahwa variabel dukungan keluarga $(\mathrm{PR}=2,015)$, pengetahuan variabel ibu $(\mathrm{PR}=2,164)$, ketersediaan variabel fasilitas perawatan kesehatan $(\mathrm{PR}=2,376)$, dan dukungan variabel untuk petugas kesehatan $(P R=3,601)$ mempengaruhi pemanfaatan layanan imunisasi IPV di Kota Palembang. Disimpulkan bahwa dukungan untuk tenaga kesehatan adalah variabel yang memiliki pengaruh terbesar terhadap pemanfaatan layanan imunisasi IPV di Kota Palembang.

Corresponding Author:

Icon Harizon

Dinas Kesehatan Provinsi Sumatera Selatan, Palembang, Indonesia

Email: iharizon@gmail.com

\section{PENDAHULUAN}

Pertemuan World Health Assembly (WHA) pada tahun 2012, menyatakan bahwa eradikasi virus polio menjadi permasalahan yang dianggap darurat untuk ditindak lanjut bagi kesehatan masyarakat global dan membuat World Health Organization (WHO) mengembangkan strategi yang komprehensif dalam eradikasi polio. Dalam strategi tersebut dibutuhkan komitmen global 
bahwa setiap negara perlu melaksanakan tahapan-tahapan yaitu Pekan Imunisasi Nasional (PIN) Polio, penggantian dari trivalent Oral Polio Vaccine (tOPV) menjadi bivalent Oral Polio Vaccine (bOPV), Introduksi Inactivated Polio Vaccine (IPV) dan penarikan seluruh vaksin polio tetes (WHO, 2014).

Kejadian poliomielitis karena poliovirus tipe 2 liar terjadi pada tahun 1999 dan poliovirus tipe 2 liar tersebut secara resmi mendapatkan sertifikasi sebagai virus yang sudah diberantas pada bulan September 2015. Virus polio liar tipe 3 tidak terdeteksi secara global sejak November 2012, kasus terakhir poliomielitis karena strain ini dilaporkan terjadi di Provinsi Yobe, Nigeria. Kasus poliomielitis paralitik akibat virus polio liar disebabkan oleh virus poliovirus tipe 1yang terus beredar di tiga negara endemik: Afghanistan, Nigeria dan Pakistan (WHO, 2017).

Indonesia melaksanakan PIN Polio tiga tahun berturut-turut pada tahun 1995, 1996 dan 1997, virus polio liar asli Indonesia (indigenous) sudah tidak ditemukan lagi sejak tahun 1996. Pada tanggal 13 Maret 2005 ditemukan kasus polio importasi pertama di Kecamatan Cidahu Kabupaten Sukabumi, Jawa Barat. Kasus polio tersebut berkembang menjadi KLB yang menyerang 305 orang dalam kurun waktu 2005 sampai awal 2006. KLB ini tersebar di 47 kabupaten/kota di 10 provinsi, Selain itu juga ditemukan 46 kasus Vaccine Derived Polio Virus (VDPV) di kabupaten di Pulau Madura dan satu kasus terjadi di Probolinggo, Jawa Timur. Setelah dilakukan Outbreak Response Immunization (ORI), dua kali mop-up, lima kali PIN, dan dua kali Sub-PIN, KLB dapat ditanggulangi sepenuhnya. Kasus Virus Polio Liar (VPL) di Indonesia terakhir yang mengalami kelumpuhan ditemukan pada tanggal 20 Februari 2006 di AcehTenggara, Nanggroe Aceh Darussalam. Sejak saat itu hingga sekarang tidak pernah lagi ditemukan kasus Polio (Kemenkes RI, 2016).

Saat ini Indonesia telah berhasil menerima sertifikasi bebas polio beserta negara anggota WHO di South East Asia Region (SEAR) pada bulan Maret 2014. Indonesia sebagai anggota WHO telah melaksanakan tahapan-tahapan dalam strategi global yang diberikan dari WHO untuk mempertahankan keberhasilan bebas polio dan melaksanakan strategi menuju eradikasi polio di dunia. Penggantian tOPV ke bOPV telah dilaksanakan serentak pada 4 april 2016, Pekan imunisasi nasional (PIN) polio dilaksanakan pada tanggal 8-15 maret 2016, Introduksi Inactivated Polio Vaccine (IPV) pada bulan september 2016 dan penarikan dan pemusnahan seluruh vaksin tOPV (Kemenkes RI, 2016; Gunardi, 2017).
Introduksi IPV yang dilaksanakan pada bulan September 2016 merubah jadwal pemberian imunisasi dasar yang diberikan oleh pemerintah secara nasional. Perubahan jadwal imunisasi yang diberikan yaitu dengan adanya penambahan jadwal imunisasi IPV pada bayi usia 4 bulan. Perubahan dalam jadwal pemberian vaksin karena adanya introduksi vaksin dapat mempengaruhi capaian cakupan program imunisasi (Kemenkes RI, 2016). Status imunisasi polio yang baik di masyarakat dapat dipertahankan bila cakupannya tinggi dan merata di seluruh wilayah di Indonesia agar tercapai tingkat imunitas polio di populasi (herd immunity) (Kemenkes RI, 2017).

Berdasarkan data Riskesdas Tahun 2013, cakupan imunisasi polio 4 untuk nasional sebesar $77 \%$, sedangkan cakupan imunisasi polio 4 di Provinsi Sumatera Selatan sebesar 76,3\%. Data subdit imunisasi Kementerian Kesehatan RI melaporkan bahwa cakupan polio 4 sebesar 91,9\% pada Tahun 2016 dan sebesar 91,1\% Pada tahun 2017, sedangkan cakupan imunisasi IPV hanya sebesar 47\%. Dinas Kesehatan Provinsi Sumatera Selatan sendiri melaporkan bahwa cakupan imunisasi polio 4 pada Tahun 2016 dan 2017 masing-masing sebesar 99,3\% dan 98,7\%, namun cakupan IPV tahun 2017 hanya sebesar 83\%. Dinas Kesehatan Kota Palembang juga melaporkan bahwa cakupan imunisasi IPV di Kota Palembang pada Tahun 2017 hanya sebesar 66,7\% (Kemenkes RI, 2013; Dinas Kesehatan Kota Palembang, 2017).

Berdasarkan uraian di atas, peneliti ingin mengetahui faktor-faktor apa saja yang berpengaruh dalam pemanfaatan layanan imunisasi IPV oleh masyarakat (ibu yang memiliki anak di bawah 1 tahun) di Kota Palembang.

\section{METODE}

Penelitian ini menggunakan desain penelitian survei analitik dengan pendekatan cross sectional, karena penelitian ini bertujuan melihat jumlah cakupan dan hubunganya dengan variabel yang di teliti.

Penelitian ini dilakukan di wilayah kerja beberapa puskesmas yang terpilih sebagai sampel penelitian yaitu Puskesmas Sosial, Puskesmas 5 Ilir, Puskesmas Kampus, Puskesmas Makrayu dan Puskesmas Karya Jaya. Penelitian ini dilakukan pada bulan September-Oktober 2018.

Populasi dalam penelitian ini adalah semua ibu yang memiliki bayi yang menjadi sasaran imunisasi IPV pada tahun 2017 di Kota 
Palembang berdasarkan data Dinas Kesehatan Kota Palembang. Sampel minimal pada penelitian ini berjumlah 360 sampel. Instrumen penelitian yang digunakan dalam penelitian ini yaitu kuesioner. Data atau informasi ini diperoleh melalui wawancara menggunakan kuesioner dengan responden yang merupakan ibu dari bayi.

Penelitian ini telah melewati kaji etik dan memperoleh Sertifikat Persetujuan Etik dengan Nomor 248/UN9.1.10/KKE/2018 oleh Komisi Etik Penelitian Kesehatan Fakultas Kesehatan Masyarakat Universitas Sriwijaya.

HASIL

Tabel 1. Distribusi Karakteristik Responden Pemanfaatan Pelayanan Imunisasi IPV

\begin{tabular}{lrr}
\hline \multicolumn{1}{c}{ Variabel } & n & \% \\
\hline Umur Ibu & & \\
$\quad$ Tidak Produktif & 69 & 17,3 \\
$\quad$ Produktif & 331 & 82,7 \\
\hline Pendidikan Ibu & & \\
$\quad$ Dasar & 131 & 32,7 \\
$\quad$ Menengah & 208 & 52,0 \\
$\quad$ Tinggi & 61 & 15,3 \\
\hline Pekerjaan Ibu & & \\
$\quad$ Tidak Bekerja & 315 & 78,7 \\
$\quad$ Bekerja & 85 & 21,3 \\
\hline
\end{tabular}

Dari tabel 1 diketahui gambaran distribusi responden yang memanfaatkan pelayanan imunisasi IPV di Kota Palembang, dari tabel dijelaskan umur ibu hampir seluruhnya berada pada kategori umur produktif (20-35 tahun) sebanyak $82,7 \%$. Variabel pendidikan ibu menunjukkan sebagian besar responden berada pada tingkat pendidikan menengah dengan persentase sebesar 52,0\%. Variabel pekerjaan ibu didominasi oleh responden yang tidak bekerja yakni sebesar 78,8\%.

Responden dalam penelitian sebagian besar dalam kelompok umur produktif (20-35 tahun). Hal tersebut akan mempengaruhi keterlibatan ibu dalam berbagai upaya pencegahan dan penanggulangan timbulnya penyakit pada anaknya, salah satunya dengan memanfaatkan layanan imunisasi bagi anaknya.

Hasil penelitian ini menunjukkan bahwa sebagian besar responden berada pada tingkat pendidikan menengah $(52 \%)$.

Tabel 2. Hubungan Pengetahuan Ibu terhadap Imunisasi IPV dengan Pemanfaatan Pelayanan Imunisasi IPV

\begin{tabular}{|c|c|c|c|c|c|c|c|}
\hline \multirow{3}{*}{ Pengetahuan Ibu } & \multicolumn{5}{|c|}{ Pemanfaatan Pelayanan Imunisasi IPV } & \multirow{3}{*}{$p$-value } & \multirow{2}{*}{$\begin{array}{c}\text { PR } \\
(95 \% \mathrm{CI})\end{array}$} \\
\hline & \multicolumn{3}{|c|}{ Ya } & \multicolumn{2}{|c|}{ Tidak } & & \\
\hline & $\mathbf{n}$ & & $\%$ & $\mathbf{n}$ & $\%$ & & \\
\hline Baik & & 197 & 89,5 & 23 & 10,5 & 0003 & 2,369 \\
\hline Kurang baik & & 141 & 78,3 & 39 & 21,7 & 0,003 & $(1,355-4,143)$ \\
\hline
\end{tabular}

Hasil uji statistik pada tabel 2 menunjukkan bahwa ada hubungan yang bermakna antara pengetahuan ibu dengan pemanfaatan pelayanan kesehatan imunisasi polio suntik (IPV) di Kota Palembang ( $p$ value $=0,003$ ). Hasil analisis diperoleh nilai $\mathrm{PR}=2,369$ dengan $95 \%$ CI: 1,355-4,143 sehingga dapat disimpulkan bahwa ibu dengan pengetahuan baik akan memanfaatkan pelayanan kesehatan imunisasi polio suntik (IPV) 2,369 kali lebih besar dibandingkan ibu dengan pengetahuan kurang.

Hasil penelitian dapat membuktikan adanya hubungan antara pengetahuan ibu dengan pemanfaatan pelayanan kesehatan imunisasi polio suntik (IPV) di Kota Palembang. Menurut asumsi peneliti, ibu yang tidak memanfaatkan layanan imunisasi dikarenakan ibu memiliki pengetahuan yang kurang mengenai imunisasi. Pengetahuan merupakan domain yang sangat penting untuk terbentuknya perilaku terbuka (overt behavior). Perilaku yang didasari pengetahuan umumnya bersifat lebih bertahan. Penelitian yang dilakukan oleh Mayasari dan Fakhidah (2016) menyatakan bahwa faktor pengetahuan memegang peranan penting dalam pemberian kelengkapan imunisasi dasar, karena pengetahuan mendorong kemauan dan kemampuan masyarakat, sehingga akan diperoleh suatu manfaat terhadap keberhasilan imunisasi secara lengkap. Pengetahuan yang diperoleh ibu bisa dipengaruhi oleh beberapa faktor antara lain pendidikan, informasi, pengalaman dan pemahaman tentang sesuatu yang dipelajari. Pendidikan sangat mempengaruhi suatu tingkat pengetahuan ibu tentang imunisasi. Pendidikan 
formal pengetahuan ibu juga dapat diperoleh dari pendidikan non formal, misalnya melalui informasi yang diperoleh lewat iklan atau penyuluhan.

Tabel 3. Hubungan Sikap Ibu terhadap Imunisasi IPV dengan Pemanfaatan Pelayanan Imunisasi IPV

\begin{tabular}{|c|c|c|c|c|c|c|}
\hline \multirow{3}{*}{ Sikap Ibu } & \multicolumn{4}{|c|}{ Pemanfaatan Pelayanan Imunisasi IPV } & \multirow{3}{*}{$p$-value } & \multirow{3}{*}{$\begin{array}{c}\text { PR } \\
(95 \% \mathrm{CI})\end{array}$} \\
\hline & \multicolumn{2}{|c|}{$\mathbf{Y a}$} & \multicolumn{2}{|c|}{ Tidak } & & \\
\hline & $\mathbf{n}$ & $\%$ & $\mathbf{n}$ & $\%$ & & \\
\hline Baik & 170 & 82,5 & 36 & 17,5 & 0324 & 0.731 \\
\hline Kurang & 168 & 86,6 & 26 & 13,4 & 0,324 & $(0,423-1,264)$ \\
\hline
\end{tabular}

Hasil analisis hubungan antara variabel sikap ibu terhadap imunisasi IPV dengan pemanfaatan pelayanan imunisasi polio suntik (IPV) di Kota Palembang pada tabel 3 diperoleh bahwa ada sebanyak $170(82,5 \%)$ ibu yang memiliki sikap baik terhadap imunisasi IPV memanfaatkan pelayanan imunisasi IPV, sedangkan diantara ibu yang memiliki sikap kurang baik terhadap imunisasi IPV terdapat 168
$(86,6 \%)$ yang memanfaatkan pelayanan imunisasi IPV. Hasil uji statistik diperoleh $p$-value $=0,324$ maka dapat disimpulkan tidak terdapat perbedaan proporsi pemanfaatan pelayanan imunisasi IPV antara ibu yang memiliki sikap baik dan ibu yang memiliki sikap kurang (tidak ada hubungan yang signifikan antara sikap ibu terhadap imunisasi IPV dengan pemanfaatan pelayanan imunisasi IPV di Kota Palembang.

Tabel 4. Hubungan Ketersediaan Sarana Pelayanan Kesehatan dengan Pemanfaatan Pelayanan Imunisasi IPV

\begin{tabular}{|c|c|c|c|c|c|c|}
\hline \multirow{3}{*}{$\begin{array}{l}\text { Ketersediaan Sarana } \\
\text { Pelayanan Kesehatan }\end{array}$} & \multicolumn{4}{|c|}{ Pemanfaatan Pelayanan Imunisasi IPV } & \multirow{2}{*}{$p$-value } & \multirow{2}{*}{$\begin{array}{c}\text { PR } \\
(95 \% \mathrm{CI}) \\
\end{array}$} \\
\hline & \multicolumn{2}{|c|}{ Ya } & \multicolumn{2}{|c|}{ Tidak } & & \\
\hline & $\mathbf{n}$ & $\%$ & $\mathbf{n}$ & $\%$ & & \\
\hline Tersedia & 277 & 88,2 & 37 & 11,8 & 0,000 & $\begin{array}{r}3,068 \\
\end{array}$ \\
\hline Tidak & 61 & 70,9 & 25 & 29,1 & 0,000 & $(1,721-5,470)$ \\
\hline
\end{tabular}

Hasil uji statistik pada tabel 4 menunjukkan bahwa ada hubungan yang bermakna antara ketersediaan sarana pelayanan kesehatan dengan pemanfaatan layanan kesehatan imunisasi polio suntik (IPV) di Kota Palembang $(p$-value $=0,000)$. Hasil analisis diperoleh nilai $\mathrm{PR}=3,068$ dengan $95 \%$ CI: 1,721 5,470 sehingga dapat disimpulkan bahwa tersedianya sarana pelayanan kesehatan akan lebih meningkatkan pemanfaatan pelayanan kesehatan imunisasi polio suntik (IPV) 3,068 kali lebih besar dibandingkan dibandingkan dengan tanpa ketersediaan sarana pelayanan kesehatan.

Menurut hasil penelitian, responden cenderung akan memanfaatkan layanan kesehatan imunisasi bila sarana pelayanan kesehatan yang menyediakan imunisasi tersebut tersedia di dekat tempat tinggalnya dan bisa dijangkau.

Tabel 5. Hubungan Akses ke Sarana Pelayanan Kesehatan dengan Pemanfaatan Pelayanan Imunisasi IPV

\begin{tabular}{lcccccr}
\hline \multirow{2}{*}{$\begin{array}{c}\text { Akses ke Sarana } \\
\text { Pelayanan Kesehatan }\end{array}$} & \multicolumn{2}{c}{ Pemanfaatan Pelayanan Imunisasi IPV } & \multirow{2}{*}{ p-value } & \multicolumn{2}{c}{ PR } \\
\cline { 2 - 5 } & \multicolumn{2}{c}{ Ya } & Tidak & (95\% CI) & \\
\cline { 2 - 6 } Baik & 152 & 83,5 & 30 & 16,4 & 0,720 & 0,872 \\
Kurang Baik & 186 & 85,3 & 32 & $-14,7$ & & $(0,507-1,499)$ \\
\hline
\end{tabular}

Hasil analisis hubungan antara akses ke sarana pelayanan kesehatan dengan pemanfaatan pelayanan imunisasi polio suntik (IPV) di Kota Palembang pada tabel 5 diperoleh bahwa ada sebanyak $152(83,5 \%)$ ibu yang memiliki akses baik ke sarana pelayanan kesehatan memanfaatkan pelayanan imunisasi IPV, sedangkan diantara ibu yang memiliki akses kurang ke sarana pelayanan kesehatan terdapat $186(85,3 \%)$ yang memanfaatkan pelayanan imunisasi IPV. Hasil uji statistik diperoleh $p$ - value $=0,720$ maka dapat disimpulkan tidak terdapat perbedaan proporsi pemanfaatan pelayanan imunisasi IPV antara ibu yang memiliki akses baik ke sarana pelayanan kesehatan dan ibu yang memiliki akses kurang ke sarana pelayanan kesehatan (tidak ada hubungan yang signifikan antara akses ke sarana pelayanan kesehatan dengan pemanfaatan pelayanan imunisasi IPV di Kota Palembang). Hasil penelitian ini adalah bahwa lokasi pemberian imunisasi mudah dijangkau oleh responden, dan 
berdasarkan hasil wawancara diketahui bahwa semua responden dengan mudah menuju ketempat pemberian imunisasi karena jarak rumah dengan tempat pelayanan imunisasi berjarak lebih dekat, walaupun ada beberapa responden yang menganggap jaraknya jauh namun masih ada alat transportasi yang dapat digunakan sehingga kebanyakan dari mereka dapat menjangkaunya.
Penelitian ini sesuai dengan penelitian Prayogo Ari dkk (2009), bahwa tidak terdapat hubungan antara jarak tempat pelayanan imunisasi dengan kelengkapan imunisasi dasar, dikarenakan pada saat penelitian, terlihat kecenderungan orang tua dengan rumah berjarak lebih dekat dengan tempat pelayanan imunisasi memiliki anak dengan imunisasi lengkap.

Tabel 6. Hubungan Dukungan Petugas Kesehatan dengan Pemanfaatan Pelayanan Imunisasi IPV

\begin{tabular}{|c|c|c|c|c|c|c|}
\hline \multirow{3}{*}{$\begin{array}{c}\text { Dukungan Petugas } \\
\text { Kesehatan }\end{array}$} & \multicolumn{4}{|c|}{ Pemanfaatan Pelayanan Imunisasi IPV } & \multirow{3}{*}{$p$-value } & \multirow{3}{*}{$\mathbf{P R}$} \\
\hline & \multicolumn{2}{|c|}{$\mathbf{Y a}$} & \multicolumn{2}{|c|}{ Tidak } & & \\
\hline & $\mathbf{n}$ & $\%$ & $\mathbf{n}$ & $\%$ & & \\
\hline Baik & 221 & 92,1 & 19 & 7,9 & \multirow{2}{*}{0,000} & 4,275 \\
\hline Kurang Baik & 117 & 73,1 & 43 & 26,9 & & $(2,383-7,670)$ \\
\hline
\end{tabular}

Hasil uji statistik pada tabel 6 menunjukkan bahwa ada hubungan yang bermakna antara variabel dukungan petugas kesehatan dengan pemanfaatan pelayanan kesehatan imunisasi polio suntik (IPV) di Kota Palembang ( $p$-value $=0,000)$. Hasil analisis diperoleh nilai $P R=4,275$ dengan $95 \%$ CI: 2,383 7,670 sehingga dapat disimpulkan bahwa adanya dukungan petugas kesehatan yang baik akan lebih meningkatkan pemanfaatan pelayanan kesehatan imunisasi polio suntik (IPV) 4,275 kali lebih besar dibandingkan dengan kurangnya dukungan petugas kesehatan.
Pada populasi dengan keyakinan 95\%, dukungan petugas kesehatan merupakan faktor pemanfaatan pelayanan kesehatan imunisasi polio suntik (IPV) dengan rentang nilai CI antara 2,383-7,670. Hal ini memiliki makna bahwa pada populasi, adanya dukungan petugas kesehatan yang baik memiliki kemungkinan 2,383 hingga 7,670 kali lebih besar untuk memungkinkan seorang ibu untuk memanfaatkan pelayanan kesehatan imunisasi polio suntik (IPV) dibandingkan dengan kurangnya dukungan petugas kesehatan.

Tabel 7. Hubungan Variabel Dukungan Keluarga dengan Pemanfaatan Pelayanan Imunisasi IPV

\begin{tabular}{|c|c|c|c|c|c|c|}
\hline \multirow{3}{*}{ Dukungan Keluarga } & \multicolumn{4}{|c|}{ Pemanfaatan Pelayanan Imunisasi IPV } & \multirow{3}{*}{ p-value } & \multirow{3}{*}{ PR } \\
\hline & \multicolumn{2}{|c|}{$\mathbf{Y a}$} & \multicolumn{2}{|c|}{ Tidak } & & \\
\hline & n & $\%$ & n & $\%$ & & \\
\hline Baik & 205 & 88 & 28 & 12 & \multirow{2}{*}{0,033} & 1,872 \\
\hline Kurang Baik & 133 & 79,6 & 34 & 20,4 & & $(1,084-3,230)$ \\
\hline
\end{tabular}

Hasil uji statistik pada tabel 7 PEMBAHASAN

menunjukkan bahwa ada hubungan yang bermakna antara dukungan keluarga dengan pemanfaatan pelayanan kesehatan imunisasi polio suntik (IPV) di Kota Palembang ( $p$ value $=0,033)$. Hasil analisis diperoleh nilai $\mathrm{PR}=1,872$ dengan 95\% CI: 1,084-3,230 sehingga dapat disimpulkan bahwa ibu dengan dukungan keluarga yang baik akan lebih meningkatkan pemanfaatan pelayanan kesehatan imunisasi polio suntik (IPV) 1,872 kali lebih besar dibandingkan dengan ibu yang kurang mendapat dukungan keluarga. Dukungan keluarga juga berkaitan dengan tradisi, apabila tradisi dikeluarga terbiasa memberikan imunisasi maka secara otomatis keluarga yang ada didalamnya juga mendukung untuk pemberian imunisasi
Hasil penelitian ini menunjukkan $84,5 \%$ responden telah memanfaatkan pelayanan imunisasi IPV di Kota Palembang tahun 2018. Angka cakupan ini lebih tinggi dibandingkan data Dinas Kesehatan Kota Palembang mengenai cakupan imunisasi IPV di Kota Palembang pada Tahun 2017 yang hanya sebesar $66,7 \%$. Ini bisa saja terjadi peningkatan banyak faktor yang menjadi penyebab kenaikan cakupan imunisasi. Adanya peningkatan dari angka cakupan pemanfaatan imunisasi IPV ini jika dikaitkan dengan teori berdasarkan kombinasi antara model penggunaan pelayanan kesehatan (Health Service Utilization Model) dan teori Lawrence W. Green, maka diduga ada faktor-faktor yang memberikan 
pengaruh yang kuat terhadap peningkatan angka cakupan tersebut. Pada penelitian ini dilihat beberapa faktor yang berhubungan dengan pemanfaatan pelayanan imunisasi IPV di Kota Palembang tahun 2018 yaitu faktor predisposisi (pengetahuan ibu dan sikap ibu), faktor pendukung (ketersediaan sarana pelayanan kesehatan dan akses ke sarana pelayanan kesehatan), dan faktor pendorong (dukungan petugas kesehatan dan dukungan keluarga). Peneliti memang mengabil beberapa faktor yang di buat penelitian dengan alasan ada beberapa faktor yang tidak bisa di interverensi dari ketiga faktor utama yang dikemukakan di atas.

Penelitian ini melibatkan 5 wilayah Puskesmas di Kota Palembang. Dari hasil wawancara dan pengisian kuesioner diketahui karakteristik individu dari responden yang terlibat dalam penelitian ini antara lain umur ibu, pendidikan ibu, dan pekerjaan ibu.

Berdasarkan umur ibu diketahui bahwa hampir seluruhnya berada pada kategori umur produktif $(82,7 \%)$ dan hanya $17,3 \%$ yang berada pada kategori umur tidak produktif. Pada penelitian ini usia produktif adalah usia antara 20 sampai dengan 35 tahun. Sejalan dengan hasil penelitian Mardiah (2010) dan Triana (2016) dimana dalam penelitian tersebut hampir seluruh respondennya adalah ibu yang berada pada kategori umur produktif.

Hal ini memang sesuai dengan kondisi di lapangan karena ibu-ibu yang menjadi responden adalah ibu yang memilki anak usia 4 bulan sampai dengan 12 bulan yang sebagian besar ibuibu dengan usia produktif. Observasi atau pengamatan peneliti dilapangan bahwa ibu yang mempunyai anak bayi di bawah dua tahun (Baduta) berada pada masa dewasa awal dengan rentang usia yang paling banyak ditemukan yaitu usia 20 tahun hingga 40 tahun. Pada usia ini tingkat kepemilikan anak pun berbeda-beda, ada beberapa responden menyatakan bahwa anak yang diberikan imunisasi merupakan anak pertamadan paling dominan yakni anak ke 2 dan anak terakhir.

Distribusi pendidikan ibu dalam penelitian ini didominasi oleh ibu berpendidikan menengah (52\%), hanya $32,7 \%$ ibu yang berada pada kategori pendidikan dasar. Pendidikan Menengah pada penelitian ini adalah pendidikan SMA atau sederajat, sedangkan pendidikan dasar adalah pendidikan anak SD dan SMP, dan pendidikan tinggi adalah pendidikan Diploma dan Sarjana. Ibu yang berpendidikan lebih tinggi cenderung lebih besar keterlibatannya dalam program pelayanan kesehatan, memiliki pengertian yang lebih baik tentang pencegahan penyakit dan mempunyai kesadaran yang lebih tinggi terhadap masalah-masalah kesehatan, sehingga ibu tersebut lebih memanfaatkan pelayanan kesehatan imunisasi dibandingkan ibu berpendidikan rendah. Ibu yang mempunyai tingkat pendidikan lanjut diperkirakan lebih mudah dalam menerima dan mengerti tentang pesan-pesan imunisasi yang disampaikan oleh petugas kesehatan, baik melalui penyuluhan maupun media massa dan elektronik, sehingga diharapkan dapat menerapkan informasi yang diterimanya, yaitu memberikan imunisasi lengkap kepada anaknya (Istriyati, 2011). Hal ini sejalan dengan temuan pemanfaatan pelayanan IPV pada penelitian ini sebesar $84,5 \%$ sejalan dengan tingkat pendidikan responden pada penelitian ini dimana sebagian besar $67,3 \%$ berpendidikan menengah sampai dengan perguruan tinggi.

Tingkat pendidikan rata-rata ibu pada 5 wilayah puskesmas Kota Palembang ini didominasi dengan ibu yang berpendidikan sekolah menengah pertama, menurut mereka pemberian imunisasi merupakan suatu hal yang penting karena hal tersebut berpengaruh terhadap derajat kesehatan anaknya kelak dan informasi yang mereka dapatkan sebelumnya ternyata tidak hanya didapatkan dari petugas pelayanan kesehatan namun didapatkan melalui materi pembelajaran yang diajarkan ketika para ibu menduduki bangku sekolah formal, lebih tepatnya pada materi pembelajaran biologi yakni mengenai berbagai macam virus. Mereka pun beranggapan bahwa semakin berkembangnya zaman tidak menutup kemungkinan virus pun menjadi lebih kuat dari sebelumnya jika masuk kedalam tubuh akan berdampak pada kesehatan terutama pada bayi masih dalam tahap perkembangan.

Hasil penelitian menunjukkan bahwa ada hubungan yang bermakna antara variabel pengetahuan ibu tentanng imunisasi IPV dengan pemanfaatan pelayanan kesehatan imunisasi polio suntik (IPV) di Kota Palembang ( $p$ value $=0,003)$. Perhitungan risk estimate, diperoleh nilai $\mathrm{PR}=2,369$ dengan $95 \%$ CI: 1,355 4,143 sehingga dapat disimpulkan bahwa ibu dengan pengetahuan yang baik terhadap imunisasi IPV lebih mungkin 2,369 kali untuk memanfaatkan pelayanan kesehatan imunisasi polio suntik (IPV) dibandingkan ibu dengan pengetahuan kurang baik terhadap imunisasi IPV.

Sebuah studi di Peru menunjukkan bahwa rasio perbandingan imunisasi pada anak dengan ibu yang berpengetahuan kurang dengan ibu yang berpengetahuan baik sebesar 1:3 (World Bank, 1994 dalam Ningrum dan Sulastri, 2008). 
Kesimpulan yang sama dari hasil survey di India oleh Nepal Demographic Health Survey (Vaessen, 2002) pada tahun 2001 tentang pemanfaatan pelayanan kesehatan pada $8726 \mathrm{ibu}$ menunjukkan, ibu yang banyak memiliki pengetahuan lebih banyak memanfaatkan fasilitas pelayanan kesehatan.

Adedire et.al. (2016) juga menemukan bahwa pengetahuan ibu sebagai determinan yang mempengaruhi kelengkapan pemberian imunisasi pada anak usia 12-23 bulan di Distrik Atakumosa Nigeria, dimana ibu yang memiliki pengetahuan yang baik tentang informasi pentingnya imunisasi lebih cenderung memanfaatkan layanan imunisasi dibandingkan ibu yang berpengetahuan kurang ( $p$-value $=0,000)$.

Berdasarkan informasi yang didapat peneliti dari ibu dilapangan bahwa ternyata pengetahuan yang didapatkan ibu tidak hanya berasal dari pengetahuan formal dan informal seperti penyuluhan saja, pengetahuan yang didapatkan ibu banyak berasal dari media sosial yang diakses oleh ibu dikarenakan tidak setiap saat ada penyuluhan dan menurut mereka metode penyampaian penyuluhan yang membosankan membuat para ibu lebih memilih mendaptkan informasi dari media elektronik khususnya sosial media dimana orang tua tetap mendapatkan informasi meskipun berada di dalam rumah, dan ada juga ibu yang memanfaatkan pelayanan kesehatan dikarenakan pengalaman anak sebelumnya, pada anak sebelumnya mereka merasa anak mereka menjadi lebih rentan terkena penyakit dan ada juga yang mengemukakan bahwa pada anak sebelumnya mereka belum terpapar informasi dikarenakan masih minimnya penyebarluasan informasi mengenai imunisasi. Sehingga Perlu sekali adanya peningkatan promosi kesehatan yang dilakukan dari berbagai macam media, baik media masa, elektronik, dan media sosial yang terus berkembang sesuai dengan perkembangan teknologi.

\section{Hubungan antara Ketersediaan Sarana Pelayanan Kesehatan dan Pemanfaatan Pelayanan Imunisasi IPV}

Hubungan antara ketersediaan sarana pelayanan kesehatan dan pemanfaatan pelayanan imunisasi IPV di Kota Palembang menunjukkan bahwa ada hubungan yang sehingga dapat disimpulkan bahwa tersedianya sarana pelayanan kesehatan 3,068 kali lebih memungkinkan seorang ibu dalam upayanya untuk memanfaatkan pelayanan kesehatan imunisasi polio suntik (IPV) dibandingkan dengan tanpa ketersediaan sarana pelayanan kesehatan.
Hasil penelitian ini sejalan dengan penelitian yang dilakukan oleh Rahman, M., \& Obaida-Nasrin, S. (2010) di Bangladesh dan Bbaale (2013) di Uganda, dimana pada kedua penelitian tersebut menyatakan bahwa tersedianya sarana pelayanan kesehatan merupakan faktor penting yang mempengaruhi cakupan pemberian imunisasi pada balita di kedua wilayah tersebut.

Pada peneletian ini, berdasarkan hasil pengamatan yang dilakukan peneliti dilapangan didapatkan bahwa pada 5 wilayah diantaranya yaitu makrayu, kampus, KM 5, kerya jaya dan 5 ilir tersedia sarana pelayanan kesehatan yang beranekaragam dan memadai, mulai dari Bidan, Dokter Prakter, Puskesmas dan rumah sakit, sehingga memudahkan ibu untuk memanfaatkan pelayanan kesehatan imunisasi suntik (IPV).

Ketersediaan Pelayanan Kesehatan Imunisasi IPV juga menjadi tanggung jawab pemerintah pusat dan daerah. Imunisasi IPV merupakan program layanan imunisasi Nasional sehingga ketersediaan vaksin dan logistik vaksin juga harus di dukung oleh pemerintah pusat dan daerah sesuai dengan PMK tahun 2017 tentang imunisasi. Selain di fasilitas pemerintah ketersediaan vaksin di fasilitas kesehatan swasta juga harus mengikuti protap penyimpanan vaksin yang baik dan benar yang harus disediakan oleh fasilitas swasta tersebut. Dengan dipenuhinya syarat penyimpanan vaksin yang baik benar maka kualitas vaksin yang akan diberikan juga akan tetap terjaga dan memberikan perlindungan yang optimal bagi yang diberikan imunisasi.

\section{Hubungan antara Dukungan Petugas Kesehatan dan Pemanfaatan Pelayanan Imunisasi IPV}

Hubungan antara Dukungan Petugas Kesehatan dan Pemanfaatan Pelayanan Imunisasi IPV di Kota Palembang menunjukkan bahwa adanya dukungan petugas kesehatan yang baik 4,275 kali lebih memungkinkan seorang ibu dalam upayanya untuk memanfaatkan pelayanan kesehatan imunisasi polio suntik (IPV) dibandingkan bila kurang mendapat dukungan petugas kesehatan.

Berdasarkan penelitian Rivka (2010) yang menyatakan ada hubungan bermakna antara keberadaan tenaga kesehatan dengan pemanfaatan pelayanan kesehatan. Petugas kesehatan di setiap sarana pelayanan kesehatan berperan sebagai pelaksana pelayanan kesehatan sehingga peran tersebut diharapkan sesuai denagan tupoksi (tugas pokok dan fungsi), pedidikan dan keterampilan yang dimilikinya. 
Penelitian ini juga sesuai dengan UndangUndang Nomor 36 Tahun 2014 tentang tenaga kesehatan yang menyatakan bahwa petugas kesehatan memiliki peranan penting untuk meningkatkan kualitas pelayanan kesehatan yang maksimal kepada masyarakat agar masyarakat mampu untuk meningkatkan kesadaran, kemauan dan kemampuan hidup sehat sehingga akan terwujud derajat kesehatan yang setinggitingginya (Hakman, 2017).

Berdasarkan hasil pengamatan yang dialukan peneliti dilapangan pada 5 Puskesmas yang menjadi tempat penelitian petugas kesehatan memberikan pelayanan yang baik terhadap masyarakat khususnya ibu yang menggunakan pelayanan imunisasi IPV, proses pemberian imunisasi terorganisir dengan baik sehingga memudahkan ibu untuk mendapatkan pelayanan imunisasi mulai dari pengambilan nomor antrian hingga pemberian imuniasi. Petugas kesehatan menjalankan prosedur dengan baik yakni dengan memberikan penjelasan ketika hendak memberikan imunisasi dan dilanjutkan dengan pemberian pengarahan setelah imunisasi sehingga ibu dapat mengetahui tindakan apa yang dilakukan kepada anak dan kejadian seperti apa yang seharusnya tidak ditakutkan oleh ibu. Pada beberapa Puskemas yang sempat peneliti lihat melakukan kegiatan penyuluhan di ruang tunggu pasien dengan menggunakan metode presentasi melalui media audiovisual seperti penampilan video maupun slide power point, sehingga para ibu yang mengantri terpapar informasi dan mengurangi kebosanan ibu ketika menunggu antrian sehingga meningkatkan kenyamanan pelayanan.

Pada Penelitian ini juga tampak sekali peran kader kesehatan sangat berperan dalam peningkatn cakupan imunisasi. Di lapangan peneliti menemukan kader yang aktif sangat berperan untuk menyebarkan informasi kepada masyarakat dan sekaligus memotivasi masyarakat untuk dapat memanfaatkan layanan kesehatan terutama imunisasi IPV. Untuk meningkatkan motivasi kader dalam membina masyarakatnya perlu sekali dilakukan pembekalan kepada kader terutama mengenai informasi terbaru mengenai informasi. Kader kesehatan di wilayah penelitian ini juga mendapatkan informasi dari petugas kesehatan puskesmas melalui pertemuan yang di adakan di puskesmas. Hal ini sejalan dengan temuan penelitian yang dibuat oleh Susanto (2017) dalam penelitian yang dilakukan mengenai kader posyandu ditemukan bahwa kader sangat berperan sebagai motivator dan penyuluh kesehatan bahkan lebih jauh lagi kader lebih mengetahui kebutuhan apa dan permasalahan apa yang terjadi di wilayah mereka. Sehingga menurut Susanto menyimpulkan juga bahwa kader posyandu yang memiliki semangat sosial tinggi dari kombinasi motivasi internal dan eksternal, sumber daya, potensi dan pengalaman dapat menginspirasi, mengantusiasi, mengaktivasi, menstimulasi, menggerakkan dan memotivasi masyarakat.

Hubungan antara dukungan keluarga dan pemanfaatan pelayanan imunisasi IPV di Kota Palembangmenunjukkan bahwa ada hubungan yang bermakna antara variabel dukungan keluarga dengan pemanfaatan pelayanan kesehatan imunisasi polio suntik (IPV) di Kota Palembang ( $p$-value $=0,033$ dengan nilai $\mathrm{PR}=1,872$ (95\% CI: 1,084-3,230) sehingga dapat disimpulkan bahwa adanya dukungan keluarga yang baik 1,872 kali lebih memungkinkan seorang ibu dalam upayanya untuk memanfaatkan pelayanan kesehatan imunisasi polio suntik (IPV) dibandingkan dengan adanya dukungan keluarga yang kurang. Penelitian ini sejalan dengan penelitian Mutmainnah (2016) dimana dalam penelitian tersebut menyatakan bahwa keluarga berperan penting dalam mempengaruhi ibu dalam pemanfaatan pelayanan imunisasi untuk bayinya $(p$-value $=0,019)$.

Adanya hubungan keluarga dengan pemanfaatan pelayanan imunisasi menunjukkan bahwa dalam memanfaatkan pelayanan imunisasi responden sangat didukung dalam memberikan pelayanan imunisasi terhadap bayinya. Artinya, keluarga mempunyai peranan yang penting dalam memberikan informasi maupun dukungan kepada responden untuk memanfaatkan pelayanan imunisasi terhadap bayinya, serta dalam meminta saran dan keputusan untuk memanfaatkan pelayanan imunisasi keluarga tetap mempunyai peranan yang sangat penting dalam hal tersebut (Schiffmann, Leon, dan Lesli, 2000; Mutmainnah, 2016).

Berdasarkan hasil observasi peneliti dengan mewawancarai responden ketika pengisian kuisioner berlangsung dan didapatkan informasi bahwa rata-rata ibu mendapatkan dukungan dari keluarga terdekat terutama suami mereka untuk memberikan imunisasi khususnya imunisasi IPV pada anaknya dikarenakan dampak yang ditimbulkan jika tidak melakukan imunisasi ini sangat berbahaya. Penentuan pelayanan kesehatan yang digunakan pun berdasrkan hasil diskusi atau kesepakatan bersama dengan keluarga dan suami dengan berlandaskan berbagai hal yakni salah satunya pengalaman sebelumnya. Dukungan Kader kesehatan juga sangat tampak pada observasi di lapangan. Kader yang aktif dapat menjadi corong informasi bagi 
masyarakat dan mengajak masyarakat untuk dapat memanfaatkan layanan kesehatan agar lebih optimal. Kader Kesehatan ini sangat berhubungan dengan pemerintahan daerah setempat dalam hal ini adalah desa, kelurahan atau kecamatan, bahkan Pemerintah daerah bupati/walikota dengan tim penggerak PKK yang ada di wilayahnya masing-masing.

\section{SIMPULAN}

Sebanyak $84,5 \%$ ibu yang memanfaatkan layanan imunisasi IPV di kota Palembang dan $15,5 \%$ ibu tidak memanfaatkan layanan imunisasi IPV di kota Palembang. Terdapat hubungan pengetahuan ibu terhadap imunisasi IPV, ketersediaan fasilitas pelayanan kesehatan, dukungan keluarga, dan dukungan petugas

\section{DAFTAR PUSTAKA}

Adedire, E. B., Ajayi, I., Fawole, O. I., Ajumobi, O., Kasasa, S., Wasswa, P., \& Nguku, P. (2016). Immunisation coverage and its determinants among children aged 12-23 months in Atakumosa-west district, Osun State Nigeria: a cross-sectional study. BMC Public Health, 16(1), 905.

Bbaale, E. (2013). Factors influencing childhood immunization in Uganda. Journal of health, population, and nutrition, 31(1), 118.

Dinas Kesehatan Kota Palembang. (2017). Profil Kesehatan Kota Palembang Tahun 2017. Palembang.

Gunardi, H. (2017). Eradikasi dan Babak Akhir Polio: Peran Tenaga Kesehatan Indonesia. eJournal Kedokteran Indonesia, 141-8.

Hakman, H., \& Saptaputra, S. (2017). Faktor yang Berhubungan dengan Pemanfaatan Pelayanan Imunisasi di Puskesmas Poasia Kota Kendari Provinsi Sulawesi Tenggara Tahun 2016. (Jurnal Ilmiah Mahasiswa Kesehatan Masyarakat), 1(3).

Istriyati, E. (2011). Faktor-Faktor Yang Berhubungan Dengan Kelengkapan Imunisasi Dasar Pada Bayi Di Desa Kumpulrejo Kecamatan Argomulyo Kota Salatiga. [Skripsi]. Semarang: Fakultas Kesehatan Masyarakat, Universitas Negeri Semarang.

Kemenkes RI. (2013). Riset Kesehatan Dasar 2013. Balitbangkes Kemenkes RI. Jakarta. kesehatan dengan pemanfaatan pelayanan kesehatan imunisasi polio suntik (IPV) di Kota Palembang, dan tidak ada hubungan sikap ibu dan akses ke sarana pelayanan kesehatan.

Peningkatan kapasitas petugas kesehatan di kabupaten kota wilayah provinsi diperlukan agar dapat memberikan pelayanan yang baik dan sesuai dengan SOP pada program imunisasi, dan selanjutnya mendorong keterlibatan pemerintah Kecamatan agar dapat melibatkan Lurah atau desa untuk membantu upaya kesehatan masyarakat khususnya imunisasi dengan pengaktifan kader diwilayah masing-masing. Bagi petugas puskesmas memberikan Pembekalan kepada Kader-kader kesehatan terkait dengan informasi terbaru mengenai imunisasi khususnya imunisasi IPV agar penyebaran informasi kepada masyarakat lebih optimal.

Kemenkes RI. (2017). PMK Kemenkes "Penyelenggaraan Imunisasi". Jakarta.

Kemenkes RI. 2016, "Petunjuk teknis pekan imunisasi Nasioanl (PIN) Polio tahun 2016". Kemenkes RI, Jakarta. 2015

Mardiah, N. (2010). Faktor-Faktor Yang Berhubungan Dengan Pemanfaatan Pelayanan Kesehatan Imunisasi Dasar Di Provinsi Kalimantan Barat Tahun 2007. [Tesis]. Depok: Fakultas Kesehatan Masyarakat, Universitas Indonesia.

Mayasari, Y. E., \& Fakhidah, L. N. (2016). Hubungan Tingkat Pengetahuan Ibu Dengan Kelengkapan Pemberian Imunisasi Dasar Di Posyandu Wilayah Puskesmas Kedunggalar. Maternal, 2(02).

Mutmainnah, M., Balqis, B., \& Darmawansyah, D. (2016). Perilaku Konsumen terhadap Pemanfaatan Pelayanan Imunisasi. Media Kesehatan Masyarakat Indonesia, 10(4), 227-233.

Ningrum, E. P., \& Sulastri, S. (2008). Faktorfaktor yang mempengaruhi kelengkapan imunisasi dasar pada bayi di Puskesmas Banyudono Kabupaten Boyolali. Berita Ilmu Keperawatan, 1(1), 7-12.

Prayogo, A., Adelia, A., Cathrine, C., Dewina, A., Pratiwi, B., Ngatio, B., ... \& Wawolumaya, C. (2016). Kelengkapan imunisasi dasar pada anak usia 1-5 tahun. Sari Pediatri, 11(1), 15-20.

Rahman, M., \& Obaida-Nasrin, S. (2010). Factors affecting acceptance of complete immunization coverage of children under 
five years in rural Bangladesh. Salud pública de méxico, 52, 134-140.

Rivka. (2010). Analisis Pemanfaatan Pelayanan Dasar Puskesmas oleh Keluarga Miskin Peserta JPKMM Di Wilayah Kecamatan Warung Kondang Kabupaten Cianjur. [Tesis]. Depok: Fakultas Kesehatan Masyarakat, Universitas Indonesia.

Schiffman, Leon, G., dan Lesli, L.K. (2000). Consumer Behavior, 7th Editon. Prentice Hall Inc. New Jersey: Upper Saddle River.

Susanto, A. (2017). Peran Kader Posyandu Sebagai Agen Perubahan Perilaku Pada Ibu Hamil Dalam Upaya Menekan Angka Kematian Ibu Dan Bayi. In Prosiding 2nd Seminar Nasional IPTEK Terapan (SENIT) 2017 (Vol. 2, No. 1, pp. 189-193).
Triana, V. (2017). Faktor yang berhubungan dengan pemberian imunisasi dasar lengkap pada bayi tahun 2015. Jurnal kesehatan masyarakat Andalas, 10(2), 123-135.

Vaessen, M. (2002). Nepal Demographic and Helath Survey (NDHS) 2001. Nepal: Family Health Division Departemen of Health Services Ministry of Health His Majesty's Government Kathmandu, New ERA Kathmandu, ORC Macro Calverton, Maryland USA.

WHO. (2017). Eradication of poliomyelitis. http://apps.who.int/gb/ebwha/pdf.

WHO. (2014). Introduction of Inactivated polio vaccienne.

www.who.int/immunization/disesase/polio myelitis. 